\title{
WHO takes action to promote health of refugees and migrants
}

Migration is a defining issue of our time. ${ }^{1}$ There are 1 billion migrants globally, of whom 258 million have crossed borders. ${ }^{2}$ Climate change and political instability propel ever-greater displacement, with major detriments to health. ${ }^{3}$ Policies that fail to prevent human trafficking or guarantee essential services to migrants undermine universal health coverage (UHC) and the global pledge in the UN 2030 Agenda for Sustainable Development to "leave no one behind". The World Health Assembly (WHA) on May 20-28, 2019, should adopt, and robustly implement, WHO's Global Action Plan on the Health of Refugees and Migrants (GAP). ${ }^{4}$

Migrants who escape from life-threatening conditions at home face manifold health threats. Migration routes can be hazardous, whether traversing desert expanses or open seas. Transit and destination countries often house migrants in unsanitary conditions, increasing the risk of transmission of communicable diseases such as cholera and tuberculosis. ${ }^{5}$ The safety of migrants is a major concem, including protecting them from sexual assault, trafficking, and forced labour. ${ }^{6}$ All-cause mortality among migrants is higher in countries with restrictive migration policies. ${ }^{7}$

Migrants often have complex physical and mental conditions but often cannot access high-quality health services. ${ }^{6}$ Most countries do not include migrants as full beneficiaries in national health coverage. Migrants are simply invisible because data disaggregation does not provide for their registration. Undocumented migrants can be classified as "criminals" under national legislation. ${ }^{8}$ Unless countries change course, migrants' right to health will not be advanced. ${ }^{9}$

Legal protection of migrants is weak compared with more structured protection afforded to refugees. Human rights apply irrespective of nationality or legal status, ${ }^{10,11}$ but states often discriminate against migrants. The 1951 Convention and its 1967 Protocol Relating to the Status of Refugees guarantee refugees the same social security as nationals, including in the event of sickness. ${ }^{12}$ However, states must determine if asylum seekers have a genuine fear of persecution. Applicants can languish without a hearing and basic rights while host countries assess applications. The European Union (EU) requires that the first country migrants enter must examine their asylum applications, resulting in disproportionate costs for EU border states. ${ }^{13}$

Refugee law should be reformed to protect asylum seekers, afford due process, and safeguard the rights and safety of all, encompassing the realities of why people flee, including environmental degradation and life-threatening poverty. National laws, moreover, frequently deny migrants equal rights to health, education, and social benefits. Only half of Refugee Convention state parties permit refugees to work. ${ }^{1}$ States should agree to a framework of assistance to support low- 
resource nations that receive many refugees or that have large numbers of irregular migrants as they extend equal rights to migrants and refugees, and the EU should promote responsibility sharing across member states.

In 2018, the UN General Assembly adopted two non-binding compacts, the Global Compact on Refugees (GCR) ${ }^{14}$ and the Global Compact for the Safe, Regular and Orderly Migration (GCM). ${ }^{15}$ GCR promotes equitable burden and responsibility sharing given that $85 \%$ of refugees flee to lower-income countries. ${ }^{16}$ For example, Colombia hosts more than 1.2 million migrants fleeing Venezuela, ${ }^{17}$ while Bangladesh has absorbed a large exodus of Rohingya peoples from Myanmar. GCR defends the principle of non-refoulment that prohibits sending refugees back to places where their lives or freedoms are jeopardised. The GCR supports rights to health, education, food, and other underlying determinants of health. The GCM emphasises migrants' human rights and building social cohesion, opposing human trafficking. This compact supports evidence-based policies to foster full inclusion, consistent with WHO's Framework of Priorities and Guiding Principles to Promote the Health of Refugees and Migrants. Quadrennial International Migration Review Forums will review implementation of the GCM.

The UN established the Network on Migration in 2018 as a system-wide mechanism for GCM implementation. WHO is among the network's 38 members, but does not sit on the Executive Committee. Other Executive Committee members, notably the UN High Commissioner for Human Rights, will need to ensure health is a priority. Similarly, without civil society or migrant representation, network members must incorporate the voices of vulnerable communities and focus on fighting discrimination and xenophobia.

The 2017 WHA directed the Secretariat to develop the GAP to improve the health of migrants and refugees. GAP priorities encompass quality health care, occupational health and safety, mental health, public health, and social determinants of health. The plan emphasises continuity of care from migrants' domestic conditions, through to their journey, and in their host countries. The GAP advocates for migrants' health rights, including gender and cultural sensitivity. WHO will support member states on cross-border collaboration, data gathering, and health policy. Additionally, WHO will promote national data systems, evidence-based policies, and education to dispel harmful misperceptions and stereotypes.

The GAP will assist states to implement the global compacts while filling gaps. Importantly, the GAP provides a mandate for WHO to provide global leadership on the health of migrants and refugees. Partnering with the International Labour Organization and UNHCR, WHO should support rights-based legal frameworks. Engagement of civil society and migrants would build bottom-up social action, while supporting inclusive participation of affected communities. 
The GAP operates within existing national legislation, which itself can be the root of unequal access to health care and social protection. WHO, therefore, should advocate for law and policy reform that guarantees equal access to all health and social benefits. For example, national policies that require health workers to inform immigration authorities about patients' legal status can deter migrants from seeking health care. Beyond support to member states, WHO should assist civil society and migrant organisations to claim their rights and take part in domestic policy making. The GAP recognises inclusive participation, which is a vital element in the right to health. ${ }^{18}$

The GAP, GCM, and GCR offer a historic opportunity to place migrant and refugee health high on the global agenda. A key step is for every state to develop a national action plan to implement the GAP priorities, embedding the health rights of migrants into domestic law. Affording migrants and refugees access to health and social protection on a fully equal basis would transform the lives of some of the world's most vulnerable people. Migrants' health will determine human development for decades to come. This is a pivotal moment to fulfil the pledge to UHC and to health equity. One day, many of us will be on the move. We owe it to current and future generations to robustly protect migrants' and refugees' health and human rights.

\section{*Lawrence O Gostin, Ibrahim Abubakar, Ranieri Guerra, Sabina FRashid, Eric A Friedman, Zsuzsanna Jakab}

0’Neill Institute for National and Global Health Law, Georgetown University Law Center, Washington, DC 20001, USA (LOG, EAF); Institute for Global Health, University College London, London (IA); World Health Organization, Geneva, Switzerland (RG , Z); and BRAC James P Grant School of Public Health, BRAC University, Dhaka, Bangladesh (SFR) gostin@law.georgetown.edu

LOG is Director of the World Health Organization Collaborating Center on National and Global Health Law. IA reports a consultancy payment to UCL from Doctors of the World. We declare no other competing interests.

2019 CWorld Health Organization. Published by Elsevier Ltd/Inc/BV. All rights reserved.

1 Abubakar I, Aldridge RW, Devakumar D, et al. The UCL-Lancet Commission on migration and health: the health of a world on the move. Lancet2018; 392: 2606-54.

2 World Health Organization. Refugee and migrant health. 2019. https://www.who.int/migrants/en/ (accessed May 3, 2019).

3 United Nations High Commissioner for Refugees. Climate change and disaster displacement. 2019. https://www.unhcr.org/climate-change-and-disasters.html (accessed April 17, 2019). 
4 World Health Organization. Promoting the health of refugees and migrants: draft action plan, 2019-2023. April 25, 2019. http://apps.who.int/gb/ebwha/pdf_files/WHA72/A72_25-en.pdf (accessed May 3, 2019).

50 'Neill Institute for National and Global Health Law. Migration, tuberculosis, and the law: an urgent need for a rightsbased approach. 2018. http://oneill.law.georgetown.edu/media/Migration-Tuberculosis-and-the-Law-An-UrgentNeed-for-a-Rights-Based-Approach.pdf (accessed April 8, 2019).

6 International Organization for Migration, World Health Organization, Office of the United Nations High Commissioner for Human Rights. International migration, health and human rights. 2013.

https://www.who.int/migrants/publications/WHO_IOM_UNOHCHR-Publication.pdf (accessed May 3, 2019).

7 Juárez SP, Honkaniemi H, Dunlavy AC. Effects of non-health-targeted policies on migrant health: a systematic review and meta-analysis. Lancet Glob Health 2019; 7: e420-35.

8 Hernandez, KL. How crossing the US-Mexico border became a crime. The Conversation, April 30, 2017. https://theconversation.com/how-crossing-the-us-mexico-border-became-a-crime-74604 (accessed May 3, 2019).

9 UN General Assembly. Transforming our world: the 2030 Agenda for Sustainable Development, UN G.A. Res. 70/1. Sept 25, 2015. http://www.un.org/ga/search/view_doc.asp?symbol=A/RES/70/1\&Lang=E (accessed April 8, 2019).

10 UN. International Covenant on Civil and Political Rights. 1966.

https://www.ohchr.org/EN/Professionallnterest/Pages/CCPR.aspx (accessed April 8, 2019).

11 UN Committee on Economic, Social and Cultural Rights. General comment no. 20: non-discrimination in economic, social and cultural rights (art. 2, para. 2). 2009. http://hrlibrary.umn.edu/gencomm/escgencom20.html (accessed April 8, 2019).

12 UN. Convention Relating to the Status of Refugees. 1951. http://hrlibrary.umn.edu/instree/v1crs.htm (accessed April 8, 2019).

13 European Parliament, Council of the European Union. Regulation (EU) No. 604/2013 of the European Parliament and of the Council of 26 June 2013. Official J European Union 2013; L180: 31-59.

14 UN. Global Compact on Refugees, UN Doc. A/73/12 (Part II). 2018. https://www.unhcr.org/gcr/GCR_English.pdf (accessed April 9, 2019).

15 UN. Global Compact for the Safe, Regular and Orderly Migration. 2018. https://refugeesmigrants.un.org/sites/default/files/180711_final_draft_0.pdf (accessed April 9, 2019). 
16 UN Refugees and Migrants. Global Compact on Refugees. 2018. https://refugeesmigrants.un.org/refugees-compact (accessed April 9, 2019).

17 Wyss J. Venezuela migration to Colombia tops 1.2 million amid crisis. Miami Herald, May 2, 2019.

https://www.miamiherald.com/news/nation-world/world/americas/colombia/article229952024.html (accessed May 3 ,2019).

18 UN Committee on Economic, Social and Cultural Rights, General Comment no. 20: the right to the highest attainable standard of health. 2000. http://hrlibrary.umn.edu/gencomm/escgencom14.htm (accessed April 9, 2019). 